\title{
Lojistik performansın pazarlama performansı ve müşteri memnuniyetine etkisi: Üretim işletmeleri üzerine bir araştırma
}

\section{The effect of logistics performance on marketing performance and customer satisfaction: A research on manufacturing companies}

\author{
${ }^{1}$ Dr. Öğr. Üyesi, Niğde Ömer Halisdemir \\ Üniversitesi, Niğde, Türkiye, \\ buketozoglu@ohu.edu.tr
}

ORCID: 0000-0003-1868-4554

2 Bilim Uzmanı, Kayseri, Türkiye,
emustafaburak@gmail.com

ORCID: 0000-0002-3884-12

ORCID: 0000-0002-3884-1249

\section{Sorumlu Yazar/Corresponding Author:}

Buket Özoğlu,

Niğde Ömer Halisdemir Üniversitesi, Niğde, Türkiye, buketozoglu@ohu.edu.tr

Başvuru/Submitted: 5/06/2021

Revizyon/Revised: 5/08/2021

Kabul/Accepted: 14/08/2021

Yayın/Online Published: 25/09/2021

Atıf/Citation: Özoğlu, B., \& Erdemir, M.B., Lojistik performansın pazarlama performansı ve müşteri memnuniyetine etkisi: Üretim işletmeleri üzerine bir araştırma, bmij (2021) 9 (3): 994-1011, doi: https://doi.org/10.15295/bmij.v9i3.1860

\author{
Buket Özoğlu ${ }^{1}$ \\ Mustafa Burak Erdemir²
}

\section{Öz}

Küreselleşme ve artan dış ticaret faaliyetleri lojistik sektörüne stratejik bir önem kazandırmıştır. Lojistik sektöründeki bu değişim üretim işletmelerinin maliyetleri ve hizmetleri üzerinde olumlu gelişmelere öncülük etmiştir. Lojistik hizmet alan üretim işletmelerinin, hizmet aldıkları lojistik firmaların performanslarının lojistik firmaların pazarlama performansına ve üretim işletmelerinin müşteri memnuniyetine etkisini değerlendirmek hem ülke ekonomisi hem de işletmelerin rekabet faktörleri açısından son derece önemlidir. Bu çalışmanın amacı, lojistik hizmet sağlayıcıların lojistik performanslarının pazarlama performanslarına ve üretim işletmelerinin müşteri memnuniyetine etkisini belirlemektir. Bu amaç doğrultusunda lojistik hizmet sağlayıcılardan hizmet alan üretim işletmelerinden yüzyüze anket yöntemiyle 400 adet veri elde edilmiştir. Verinin analizinde yapısal eşitlik modeli kullanılmış, SPSS ve AMOS paket programları ile analizler gerçekleştirilmiştir. Analiz sonuçlarına göre doğrudan etkilere bakıldığında lojistik performansın pazarlama performansı üzerinde $0,75^{\prime}$ lik ve lojistik performansın müşteri memnuniyeti üzerinde $0,38^{\prime}$ lik olumlu bir etkisi olduğu bulunmuştur. Diğer taraftan, lojistik performansın pazarlama performansı ve müşteri memnuniyetine etkisini bir arada incelediğimiz modele göre lojistik performansın müşteri memnuniyetine etkisinde pazarlama performansının kısmi aracılık etkisi olduğu belirlenmiştir.

Anahtar Kelimeler: Lojistik Performans, Pazarlama Performansı, Müşteri Memnuniyeti, Yapısal Eșitlik Modeli

Jel Kodlari: M31, L25, L84

\begin{abstract}
Globalization and increasing foreign trade activities have given the logistics sector strategic importance. This importance has led to developments that positively affect the costs and services of manufacturing companies. Therefore, evaluating the logistics performance of the logistics service providers (LSPs) on the marketing performance of LSPs and customer satisfaction of manufacturing companies is crucial in terms of both the country's economy and the competitiveness of the businesses. This study aims to determine the effect of logistics performance on LSPs' marketing performance of LSPs and the customer satisfaction of manufacturing companies. Four hundred data were obtained from manufacturing companies outsourcing logistics through the face-to-face survey method. A structural equation model was used in the study, and analyzes were conducted with SPSS and AMOS statistical programs. As a result, it was found that logistics performance directly affects marketing performance with a value of 0.75 and customer satisfaction with 0.38 . Also, it has been determined that marketing performance has a partial mediating effect on the relationship between logistics performance and customer satisfaction.
\end{abstract}

Keywords: Logistics Performance, Marketing Performance, Customer Satisfaction, Structural Equation Model

Jel Codes: M31, L25, L84 


\section{Extended Abstract}

\section{The effect of logistics performance on marketing performance and customer satisfaction: A research on manufacturing companies}

\section{Literature}

This study aims to investigate the effect of logistics performance on marketing performance and customer satisfaction. The study is significant for both logistics service providers and manufacturing companies since the marketing performance of logistics service providers is decisive in the decision processes of manufacturing companies regarding logistics activity providers. Furthermore, since the study results will directly contribute to the development of the logistics service providers, it is expected to contribute to the competitiveness and development of manufacturing companies indirectly. On the other hand, this study on logistics activities will also contribute to the developing logistics literature.

It is vital that logistics service providers, which are gaining more importance, convey the opportunity to gain a competitive advantage and increase customer satisfaction through their services to producers with an effective marketing program. Therefore, in addition to logistics performance, marketing performance and customer satisfaction should also be evaluated. Although there are some studies in the literature about logistics performance, it has been seen that these studies primarily examine the effect of logistics performance or capabilities on business performance (Fugate, Mentzer and Stank, 2010; Ilic and Tesic, 2016; Fawcett, Stanley and Smith, 1997; Qadir and Amjad, 2017). Fabbe-Costes and Jahre (2007) stated confusion between logistics performance and integration due to the literature's different and often limited definitions of performance and integration. Thus, studies on logistics/marketing integrations in the literature were also included in the literature review. Vallet-Bellmunt and Rivera (2018) examined the relationship between marketing and logistics performance in the context of integration between producers and intermediary businesses. Daugherty, Chen, Mattioda and Grawe (2009) and Ellinger, Daugherty and Keller (2000) examined the effect of marketing and logistics integration on logistics performance; Stank, Daugherty and Ellinger (1999) assessed the effect of logistics and marketing performances on business performance. On the other hand, a limited number of studies focused on the relationship between logistics performance and customer satisfaction (Li, 2011; Leuschner, Lambert and Knemeyer, 2012; Ltifi and Gharbi, 2015; Özoğlu and Büyükkeklik, 2017).

\section{Methodology}

This study is an applied study, and the main objective is to determine the effect of logistics performance on marketing performance and customer satisfaction. The study population consists of manufacturing companies operating in Istanbul and receiving logistics services. Therefore, it was not appropriate to reach the entire population due to time and cost constraints. The sufficient sample size is 384 with a $95 \%$ confidence level and a 5\% margin of error (Sekaran, 1992; Altunışık, Coşkun, Bayraktaroğlu and Yıldırım, 2007). Four hundred usable data were obtained in the study in which convenience sampling, one of the non-random sampling methods, was used.

In the data collection phase of the study, a face-to-face survey method was preferred. In the first part of the questionnaire, questions to determine the characteristics of the business, in the second part, the logistics performance scale consisting of 20 statements for measuring the performance of the logistics enterprises from which the manufacturing companies outsource, in the third part, questions for measuring the marketing performance consisting of 29 statements, and in the last part, the scale consisting of 4 statements for measuring customer satisfaction were used. The logistics performance scale is primarily adapted from the scale used by Özoğlu and Büyükkeklik (2017) with additions from Doney and Cannon (1997). The metrics that make up the marketing performance have been chosen among non-financial metrics with the approach of measuring marketing performance from the perspective of the customer, which has gained importance in recent years and is suitable for the fiction of this study (Ambler, Kokkinaki and Puntoni, 2004; Hacıoğlu and Gök, 2013). These metrics determined for the study are marketing performance metrics consisting of an expression about service quality and customer promotion activities. In this study, Stank et al. (1999)'s customer satisfaction scale was used to measure satisfaction. Each scale statement was created with a 5-point Likert rating from "Strongly Disagree" to "Strongly Agree".

Exploratory factor analysis and reliability analysis (Cronbach's alpha) were performed on the obtained data to determine the validity and reliability of the scales used in the study. Then the explained factor structure was verified by subjecting it to Confirmatory factor analysis (CFA). Finally, the verified inter-structure relationships were tested with structural equation modelling.

\section{Findings and discussion}

Within the scope of the research, first, validity and reliability analyzes of each scale used were conducted. As a result of the exploratory factor analysis for the logistics performance scale, a 3-dimensional structure was obtained, similar to the original scale, with the 1st dimension "Cost Performance", the 2nd dimension "Operational Performance", and the 3rd dimension "Relationship Performance". While the operational performance dimension alone explains $37.25 \%$ of the scale, the relationship performance dimension $23.29 \%$, the cost performance dimension $13.81 \%$, and the three dimensions explain $74.32 \%$ of the total variance. When the Cronbach's Alpha value of each dimension was examined to determine the scale's internal consistency, it was found that the reliability levels were relatively high, above 0.9 . Next, the structure that emerged from exploratory factor analysis for the logistic performance scale was tested with CFA. It was determined that most of the fit criteria values obtained from the analysis were in the perfect fit range, so the three-dimensional structure was confirmed.

As a result of the exploratory factor analysis for the marketing performance scale used in the research, a 3-dimensional structure has emerged. While the reliability/responsiveness dimension alone explains $30.26 \%$ of the scale, the marketing communication/development dimension explains $19.40 \%$, the empathy/assurance dimension explains $18.61 \%$, and all three dimensions together account for $68.27 \%$ of the total variance. It was determined that the reliability level of the reliability/responsiveness dimension (Cronbach's Alpha: 0.960), the marketing communication/development dimension (Cronbach's Alpha: 0.910) and the empathy/assurance dimension (Cronbach's Alpha: 0.926) were high. The three-dimensional structure determined by Exploratory Factor Analysis for the marketing performance scale was tested with Confirmatory Factor Analysis (CFA). It has been observed that almost all of the obtained fit criteria values comply with the perfect fit criteria.

Exploratory Factor Analysis was performed for the customer satisfaction scale, and a one-dimensional structure with a high level of reliability was determined (Alpha: 0.920 ). Similar to the other two scales, it was determined that the CFA values of the customer satisfaction scale meet the perfect fit criteria. 
After this stage, the effect of logistics performance on marketing performance was examined, and it was determined that logistics performance has a positive effect on marketing performance with a value of 0.75 , statistically at $99 \%$ confidence level $(\beta=0.75$; $t=9.24>2.58 ; p<0.01)$. Finally, the effect of logistics performance on customer satisfaction was examined, and it was found that logistics performance has a positive effect on customer satisfaction with a value of 0.38 , statistically at $99 \%$ confidence level $(\beta=0.38 ; t=6.35>2.58 ; p<0.01)$.

In the triple model where all effects were considered, it was found that logistics performance had a positive effect on marketing performance with a value of 0.70 and marketing performance has a positive effect on customer satisfaction with a value of 0.86 , statistically at a $99 \%$ confidence level. This result indicates that when there is a unit increase in logistics performance, there will be a $0.70 \%$ increase in marketing performance $(\beta=0.70 ; t=8.47>2.58 ; \mathrm{p}<0.01)$ and this increase in marketing performance will result in a $0.86 \%$ increase in customer satisfaction levels $(\beta=0.86 ; \mathrm{t}=8.81>2.58 ; \mathrm{p}<0.01)$. Thus, while the direct effect of logistics performance on customer satisfaction is 0.38 , it has become -0.18 through marketing performance. Thus, while logistics performance alone explains $14 \%$ of customer satisfaction, it is understood that marketing performance explains customer satisfaction as high as $55 \%$ with a partial mediation effect.

\section{Conclusion, recommendation and limitations}

As a result of the analyzes carried out by the objectives of the study, the scale used to measure logistics performance consists of three dimensions similar to the studies in the literature (Özoğlu and Büyükkeklik, 2017). If it is ranked according to the explanatory power, it can be said that the dimensions specified as operational performance, relationship performance and cost performance explain $74 \%$ of the total variance. Therefore, it can be suggested to focus on operational issues such as understanding logistics needs, delivery dates, and durations to improve enterprises' logistics performance. Regarding improving relationship performance, it can be suggested to focus on developing communication for reconciliation and cooperation, be solution-oriented, and focus on business goals together.

On the other hand, the three-dimensional Marketing Performance Scale explains the marketing performance of logistics enterprises by $68.27 \%$. This ratio is sufficient but relatively low can be explained by the fact that the marketing performance criteria are incredibly diverse, and the financial criteria, which have been extensively researched before, were not used in this study. It was determined that the reliability/responsiveness dimension has the highest explanation rate out of the three dimensions that explain marketing performance with a value of $30 \%$. Accordingly, it can be suggested that logistics service providers focus on delivering the services they promised on time, being reliable, and providing quick solutions to problems.

It has been determined that logistics performance has a positive effect of 0.75 on marketing performance and 0.38 on customer satisfaction. Therefore, it can be said that the increase in logistics performance has a very high effect on marketing performance, and it has a substantial effect on customer satisfaction. In addition, the effect of logistics performance on customer satisfaction is mediated by marketing performance. At this point, the direct effect of logistics performance on customer satisfaction needs to be empirically investigated as there are few related studies (Leuschner et al., 2012; Ltifi and Gharbi, 2015) and conflicting findings in the literature. On the other hand, partial mediation of marketing performance in logistics performance on customer satisfaction is expected. Therefore, increasing the logistics performance of enterprises will not have the desired effect if they do not improve the communication with their customers. In this direction, it can be suggested that logistics service providers should strive for marketing performance and the service they provide.

Since the marketing performance criteria are highly diverse and financial were not used in this study, the marketing performance of logistics enterprises can be re-evaluated by taking different marketing performance criteria into the scope of the study in future studies. In addition, it can be contributed to the literature by examining the direct effect of logistics performance on customer satisfaction, which is limited in the literature, in different samples. 


\section{Giriş}

Günümüzde işletmeler arası rekabetin artması, üretimin esnekleşmesi, dünya pazarının tek bir bütün olarak görülmesiyle, müşteri istek ve ihtiyaçlarına zamanında cevap verebilme işletmelerin varlığını sürdürebilmesi açısından önemli hale gelmiştir. Bu rekabet ortamında karlılığın arttırılması ve pazar büyüklüğünün korunmasının temel koşullarından biri de ürünlerin maliyetlerini düşürerek, rekabet edilebilir fiyatlar sunabilmektir. Lojistik faaliyetler, minimum maliyetler ile ürünlerin zamanında piyasaya sunulmasının vazgeçilmez bir unsuru haline gelmiştir. Ayrıca, işletmeler ana faaliyetlerine daha iyi odaklanabilmek için lojistik faaliyetlerde dış kaynak kullanımına giderek lojistik hizmet sağlayıcılar ile iş birliği içine girmektedir.

Küresel rekabetin lojistik faaliyetler merkezli bir yöne doğru kayması, bu faaliyetlerin gerçekçi ve net şekilde planlanmasına olan gereksinimin artmasına neden olmaktadır. Planlamaların kolaylaşması ve lojistik hizmetlerin başarısının değerlendirilmesi için de performansının ölçülmesi önemlidir. Diğer taraftan performans ölçümü, bir işletmenin tüm alanlarını ve katmanlarını kapsayan geniş, çok disiplinli ve fonksiyonlar arası bir faaliyettir (Marr ve Schiuma, 2003: 680). Dolayısıla son y1llarda önem kazanan lojistik faaliyetleri işletmelere sunan lojistik hizmet sağlayıcıların hem lojistik faaliyetlerin performansının ve hem de pazarlama performansının değerlendirilmesi kritik önemdedir. Satış büyümesi, müşteri yöneliminin arttırılması, uzun vadeli performans ölçümüne duyulan ihtiyaç ve daha iyi hesap verilebilirlik talepleri nedeniyle pazarlama performansina artan ilgi, pazarlama aktiviteleri ve iş performansı arasındaki ilişkiye odaklanmıştır. Ancak, pazarlama faaliyetlerinin standartlarının belirlenmesi ve kontrol edilmesinin zor olmasından dolayı (Bozac1, 2014: 47) pazarlama uygulamasında en fazla göz ardı edilen konu pazarlama performansının değerlendirilmesi ve kontrol edilmesidir. Lojistik hizmet sağlayıcıların, üretim işletmelerini rekabette öne geçirecek lojistik faaliyetleri müşterisi olan üretim işletmelerine güçlü bir pazarlama programıla doğru iletmesi ve memnuniyet sağlaması gerekmektedir.

Bu çalışmanın amacı, lojistik faaliyetlerin lojistik firmaların pazarlama performansına ve üretim işletmelerinin müşteri memnuniyetine etkisini araştırmaktır. Lojistik hizmet sağlayıcıların pazarlama performanslarının üretim işletmelerinin lojistik faaliyetleri devredeceği işletmelerle ile ilgili karar süreçlerinde belirleyici olmasından dolayı çalışmanın hem lojistik hizmet sağlayıcılar hem de üretim işletmeleri açısından önemli olduğu düşünülmektedir. Çalışma sonuçlarının ülke ekonomisi için son derece önemli görülen lojistik sektörünün gelişimine, üretim işletmelerinin rekabet gücüne sağlayacağ1 katkının öneminden dolayı üretim işletmelerinin lojistik faaliyetleri ile ilgili karar süreçlerine ve kendi gelişimini değerlendirebilmek açısından lojistik hizmet sektörüne katkı sağlaması beklenmektedir. Diğer taraftan, lojistik faaliyetlerle ilgili bu çalışma henüz gelişmekte olan lojistik literatürüne de katkı sağlayacaktır.

Giriş, literatür taraması, metodoloji, bulgular, sonuç ve önerilerden oluşan çalışmanın giriş bölümünde lojistik performansın ölçülmesinin önemi ve pazarlama performansı ile ilişkisine değinilmiştir. Literatür taraması kısmında lojistik performans ile pazarlama performansı ve müşteri memnuniyeti ilişkisine dair çalışmalara yer verilmiştir. Metodoloji kısmında uygulama yönteminin ayrıntıları açıklanmış, veri toplama yöntemi, ölçek ve örneklemden bahsedilmiştir. Bulgularda öncelikle verilerin analizine ilişkin yöntemler paylaşılmış, bu yöntemlerle yapılan analiz bulguları alt başlıklar halinde verilmiştir. Sonuç ve öneriler kısmında ise bulgular yorumlanarak işletmelere bu doğrultuda önerilerde bulunulmuştur.

\section{Literatür taraması}

Lojistik hizmet sağlayıcıların üretim işletmelerine sunacakları hizmetler sayesinde temel yeteneklerine odaklanarak, müşteri memnuniyetini arttırma ve böylece rekabet avantajı kazandırma imkânını güçlü bir pazarlama programıla iletmesi önemlidir. Bu kapsamda, lojistik hizmet sağlayıcıların lojistik performanslarının yanı sıra pazarlama performanslarının ve müşteri memnuniyetinin de değerlendirilmesi gerekmektedir. Son yıllarda gittikçe önem kazanan lojistik hizmet sağlayıcıların performanslarına yönelik literatürde bazı çalışmalar bulunmakla birlikte, çalışmaların çoğunlukla lojistik performansla işletme performansı arasındaki ilişkiyi inceledikleri görülmüştür.

Qadir ve Amjad (2017), Pakistan mobilya endüstrisinde lojistik süreçler, müşteri hizmetleri ve işletme performansı arasındaki ilişkiyi incelemiştir. Lojistik süreçler, müşteri hizmetlerini ve işletme performansını pozitif yönde etkilerken; üretim esnekliği, lojistik süreçler ve müşteri hizmetlerini aynı şekilde etkilememiştir. Fugate, Mentzer ve Stank (2010) lojistik performansın işletme performansına olan etkisini incelerken lojistik performansın modellenmesinde verimlilik, etkinlik ve farklılaşma arayışını temel almışlardır. Çalışma sonuçları lojistik performansın işletme performansını olumlu yönde etkilediğini göstermiştir. Fawcett, Stanley ve Smith (1997), lojistik yeteneklerin (taşıma, depolama, sipariş işleme, talep tahmini) geliştirilmesinin işletme performansını arttırdığını 
belirlemiştir. Ilic ve Tesic (2016), tedarik zinciri stratejisinin lojistik ve pazarlama performanslarıyla olan ilişkisini Sırbistan'daki bira fabrikalarına uygulayarak test etmiştir. Sonuçlar lojistik performansın işletme performansı (finans ve pazarlama) ile önemli bir ilişkisi olduğunu göstermiştir.

Lojistik performans ile müşteri memnuniyeti ilişkisine odaklanan oldukça sınırlı sayıda çalışmaya ulaşılmıştır. Li (2011), lojistik hizmet performansını üreticilerin gözünden değerlendirerek; lojistik performans geliştirildiğinde üreticilerin algıladığı katma değerli faydaların ve işbirlikçi faydaların daha yüksek bir memnuniyetle sonuçlandığını saptamıştır. Leuschner, Lambert ve Knemeyer (2012), lojistik performansın genel müşteri memnuniyetini doğrudan etkilediğini tespit etmiştir. Ltifi ve Gharbi (2015), perakende mağazalardaki lojistik performansın tüketicilerin mutluluğu ve memnuniyeti üzerindeki etkisini test etmişlerdir. Çalışma sonuçları lojistik performansın mutluluk ve memnuniyeti olumlu ve önemli ölçüde etkilediğini göstermiştir. Özoğlu ve Büyükkeklik (2017) ise lojistik hizmet sağlayıcılardan hizmet alan üretim işletmelerine yönelik yaptıkları araştırmada; lojistik performansın üç boyutu olan maliyet, ilişki ve operasyonel performansın müşteri memnuniyetine etkisini belirlemişlerdir.

Lojistik performansa odaklanarak yapılan taramalarda pazarlama performansı ile ilişkisini inceleyen çalışmalara ulaşılamamıştır. Lojistik ve pazarlama performansını bir arada inceleyen çalışmalara yönelik taramalar yoğunlaştırıldığında ise; lojistik ve pazarlama entegrasyonu ile ilgili ve bu entegrasyonun performansa etkisini inceleyen oldukça fazla çalışmaya rastlanmıştır. Akdoğan ve Durak (2016), Almanya'da ve Türkiye'deki lojistik işletmelerinden 153'ünden veri toplayarak yaptığ1 çalışmada; firmaların lojistik performansları ve pazarlama performanslarını karşılaştırmıştır. Almanya'nın lojistik alt yapısının daha güçlü olması maliyetlerin azaltmasına, hizmet kalitesinin yüksek olmasına neden olduğu için Almanya'daki işletmelerin lojistik performans ve pazarlama performansları ile Türkiye'dekiler arasında önemli farklılıklar bulunmuştur. Green, Whitten ve Inman (2008), tedarik zinciri stratejisi, lojistik performans ve pazarlama performansının işletmelerin finansal performansı üzerindeki etkilerini incelemişlerdir. Çalışmada lojistik performansın pazarlama performansını pozitif yönde etkilediği belirtilmiş, sonuç olarak da bu etkilerin işletmenin finansal performansını arttırdığı görülmüştür.

Fabbe-Costes ve Jahre (2007), lojistik performans ve entegrasyon arasında literatürde meydana gelen karışıklıkları gidermek için yaptığı çalışmada ilgili makalelerin analizinde performansın yanı sıra entegrasyonun farklı ve genellikle sınırlı şekillerde tanımlandığı, ampirik kanıtların netleşmesine izin vermeyecek şekilde işletildiği ve ölçüldüğü sonucuna varmıştır. Bu doğrultuda literatürde lojistik / pazarlama entegrasyonlarını konu alan araştırmalar da çalışmaya yön vermesi açısından literatür taramasına dahil edilmiştir. Vallet-Bellmunt ve Rivera-Torres (2018), üreticiler ile aracı işletmeler arası entegrasyon bağlamında pazarlama ve lojistik performans ilişkisini incelemiştir. Sonuç olarak kısa vadeli lojistik performans (lojistik kalitesi ve lojistik maliyetleri) ve uzun vadeli lojistik performansin (lojistik hizmeti) her ikisinin de pazarlama performansı (ilişkisel performans ve ticari performans) ile doğrudan ve pozitif olarak ilişkili olduğunu bulmuşlardır. Gimenez ve Ventura (2005), lojistik-üretim ve lojistik-pazarlama arayüzlerinin iç ve dış entegrasyonlarla olan ilişkisini incelemiş, bu iç ve dış ilişkilerin işletmelerin lojistik performansı üzerindeki etkisi üzerinde durmuştur. Lojistik-pazarlama arayüzündeki olmasa da, lojistik-üretim arayüzünde tedarik zinciri üyeleri arasındaki dış işbirliğinin işletmelerin lojistik performansına olumlu katkıda bulunduğu sonucuna ulaşılmıştır. Morash, Dröge ve Shawnee (1996) lojistik, pazarlama, üretim ve yeni ürün geliştirme için fonksiyonel, arayüz ve genel iş performansı ilişkisini incelemiştir. Departmanlar arası süreç mükemmelliği açısından, iyi performans gösteren işletmelerin diğer tüm fonksiyonel alanlarda iyi performans gösterme eğiliminde olduğunu ortaya koymaktadır ayrıca müşteri hizmetleri ve lojistik kalitesinin yetenekleri işletme performansı üzerinde en büyük bağımsız etkiye sahiptir sonucuna ulaşılmıştır. Daugherty, Chen, Mattioda ve Grawe (2009), pazarlama ve lojistik arasındaki ilişki etkinliği ile yeteneklerin geliştirilmesini ve bunun lojistik performansa etkisini açıklamıştır. Sonuç olarak pazarlama yeteneklerinin lojistik performansı olumlu yönde etkilediği vurgulanmaktadır. Ellinger, Daugherty ve Keller (2000) de benzer şekilde pazarlama/lojistik bölümleri arasındaki entegrasyon ile performans (nesnel ve sübjektif) arasında güçlü bir pozitif ilişki tespit etmiştir. Stank, Daugherty ve Ellinger (1999), lojistik ve pazarlama performanslarının işletme performansına etkisini incelediği çalışmasında pazarlama ve lojistik bölümleri arası ilişkilerin etkinliği arttığı durumlarda işletme performansının yükseldiği sonucuna ulaşılmıştır. Sezen (2005), pazarlama ve lojistik fonksiyonlarının işletme performansı üzerindeki ayrı ve entegre etkilerini incelemiştir. Pazarlama ve lojistik fonksiyonları arasında etkin bir koordinasyon bulunduğunda elde edilen genel iş performansının, görevlerin ayrı ayrı gerçekleştirildiği zaman elde edilen performansın oldukça üstünde olabileceği gösterilmiştir.

Yapılan literatür taramasına göre lojistik performans üzerine odaklanan çalışmaların çoğunlukla lojistik performansın işletme performansına etkisini incelediği görülmüştür. Lojistik ve pazarlamayı bir arada 
ele alan çalı̧̧malara bakıldığında ise; lojistik pazarlama entegrasyonunun performansa etkisi üzerine odaklanıldığı söylenebilir. Bununla birlikte, lojistik performansın müşteri memnuniyeti ile ilişkisi literatürde oldukça sınırlı incelenen konulardandır. Lojistik hizmet sağlayan işletmelerin performanslarına yönelik çalışmalara rağmen, lojistik işletmelerin lojistik performansları ile pazarlama performansının ve müşteri memnuniyetinin araştırıldığı yeterli sayıda çalışmaya ulaşılamamış ve literatürde bu konuda bir eksiklik olduğu değerlendirilmiştir. Bu sonuçlardan hareketle lojistik performansın işletmelerin pazarlama performansına ve müşteri memnuniyetine etkisi bir saha araştırması ile test edilmiştir.

\section{Metodoloji}

Çalışmanın veri toplama aşamasında anket yöntemi kullanılmıştır. İşletmelerden toplanacak veri için cevaplanma oranını yükseltmek amacıyla yüzyüze anket yöntemi tercih edilmiştir. Anket formunun birinci kısmında, işletme özelliklerini belirlemeye yönelik sorular, ikinci kısmında işletmelerin hizmet aldıkları lojistik işletmelerin performansının ölçülmesine yönelik 20 ifadeden oluşan lojistik performans ölçeği, üçüncü kısmında 29 ifadeden oluşan pazarlama performansının ölçülmesine yönelik sorular, son kısmında ise müşteri memnuniyetinin ölçülmesine yönelik 4 ifadeden oluşan ölçek kullanılmıştır.

Araştırmada ölçülmek istenen lojistik performans ölçeği büyük oranda Özoğlu ve Büyükkeklik (2017) tarafından uyarlanan ölçekten alınmış; Doney ve Cannon'dan (1997) eklemeler yapılmıştır. Pazarlama performansını oluşturan metrikler literatürde üzerinde fikir birliğine varılamamış konulardandır (Grønholdt ve Martensen, 2006: 244). Pazarlama performansı ölçeği literatürde yer alan pek çok pazarlama performans metriği arasından son yıllarda önem kazanan, bu çalışmanın kurgusuna uygun olan müşteri gözüyle pazarlama performansının ölçülmesi yaklaşımıyla finansal olmayan metrikler arasından seçilmiştir (Ambler, Kokkinaki ve Puntoni, 2004; Hacıoğlu ve Gök, 2013). Çalışma için belirlenen bu metrikler hizmet kalitesi ve müşterilere yönelik tutundurma faaliyetleri ile ilgili ifadelerden oluşan pazarlama performansı metrikleridir. Müş̧eri memnuniyetini ölçmek için ise Stank vd. (1999)'un müşteri memnuniyeti ölçeğinden yararlanılmıştır. Bu çalışmadaki veri toplama aracında yer alan lojistik performans, pazarlama performansı ve müşteri memnuniyeti ölçeklerindeki tüm ifadeler "Kesinlikle Katılmıyorum"dan "Kesinlikle Katılıyorum"a kadar 5'li Likert derecelemesi ile oluşturulmuştur.

Araştırmanın evrenini İstanbul ilinde faaliyet gösteren ve lojistik hizmet alan üretim işletmeleri oluşturmaktadır. Zaman ve maliyet kısıtları nedeniyle ana kütlenin tamamına ulaşmak mümkün olmamıştır. Örneklem hacmi ile ilgili \%95 güven düzeyi ve $\% 5$ hata payı ile 384 örneklem büyüklüğü yeterli olarak belirtilmektedir (Sekaran, 1992: 253; Altunışık, Coşkun, Bayraktaroğlu ve Yıldırım, 2007: 136-137). Tesadüfi olmayan örnekleme yöntemlerinden kolayda örnekleme yönteminin kullanıldığı araştırmada 400 adet kullanılabilir veri elde edilmiştir.

\section{Analiz ve bulgular}

Araştırma kapsamında elde edilen veriler SPSS 24 ve AMOS programı ile analiz edilmiştir. Araştırmaya katılan işletme özelliklerine göre dağılımlarının belirlenmesi için frekans analizi kullanılmıştır. Ölçeklerin geçerlilik ve güvenirlik analizi için keşifsel faktör analizi ve güvenirlik analizi (Cronbach's alpha) yapılmış, daha sonra açıklanan faktör yapısı AMOS programı yardımı ile DFA (Doğrulayıcı faktör analizi)'ne tabii tutularak doğrulanmıştır.

\section{İşletme özellikleri}

Araştırma kapsamındaki işletmelerin özelliklerinin belirlenmesi için sırası ile; sektör, çalışan sayısı, pazar, lojistik firmasından alınan hizmet türü, firmadan haberdar olma şekli sorulmuştur. İşletmelerin özelliklerine ait bulgular Tablo 1'de sunulmuştur.

Araştırma kapsamındaki işletmelerin özellikleri incelendiğinde, işletmelerin \%18,3'ünün perakende, \%19,82'sinin ilaç, \%26,8'inin gıda, \%16,5'inin teknoloji ve \%18,8'inin tekstil sektöründe oldukları belirlenmiştir. İşletmelerin \%22,8' inin 50 veya altında çalışanı olduğu, \%18,30'unun 51-100, \%15,5'inin 101-200, \%18,8'inin 201-300 ve \%24,8'inin 300 veya üzerinde çalışana sahip olduğu belirlenmiştir. İşletmelerin \%66,8'i sadece yurt içine hizmet verirken, \%18,3'ünün sadece yurt dışına, \%15'inin her iki pazara da hizmet verdiği belirlenmiştir. İşletmelerin \%30,3'ü ulaştırma, \%10,5'i gümrükleme, \%29,8'i depolama ve \%29,5'i katma değerli hizmetler alırken; \%27,3'ü işletmeden internet sitesi sayesinde haberdar oldukları, \%19'unun kulaktan kulağa iletişim sayesinde haberdar oldukları, \%53,8'inin ise gönderilen satış temsilcisi vasıtası ile haberdar oldukları belirlenmiştir. 
Tablo 1: İşletmelerin Özelliklerine Ait Bulgular

\begin{tabular}{|c|c|c|c|}
\hline Özellikler & Grup & $\mathrm{f}$ & $\%$ \\
\hline \multirow{5}{*}{ Sektör } & Perakende & 73 & 18,30 \\
\hline & İlaç & 79 & 19,80 \\
\hline & Gida & 107 & 26,80 \\
\hline & Teknoloji & 66 & 16,50 \\
\hline & Tekstil & 75 & 18,80 \\
\hline \multirow{5}{*}{ Çalışan Sayısı } & 50 veya alt1 & 91 & 22,80 \\
\hline & $51-100$ & 73 & 18,30 \\
\hline & $101-200$ & 62 & 15,50 \\
\hline & $201-300$ & 75 & 18,80 \\
\hline & 300 üzeri & 99 & 24,80 \\
\hline \multirow{3}{*}{ Pazar } & Yurt içi pazar & 267 & 66,80 \\
\hline & Yurt dişı pazar & 73 & 18,30 \\
\hline & Her iki pazar & 60 & 15,00 \\
\hline \multirow{4}{*}{ Hizmet Adı } & Ulaştırma & 121 & 30,30 \\
\hline & Gümrükleme & 42 & 10,50 \\
\hline & Depolama & 119 & 29,80 \\
\hline & Katma değerli hizmetler & 118 & 29,50 \\
\hline \multirow{4}{*}{$\begin{array}{l}\text { Firmadan Haberdar Olma } \\
\text { Şekli }\end{array}$} & İnternet sitesinden & 109 & 27,30 \\
\hline & Kulaktan kulağa iletişimle (tavsiye üzerine) & 76 & 19,00 \\
\hline & Gönderdikleri satış temsilcisi vasıtası ile & 215 & 53,80 \\
\hline & Toplam & 400 & $\mathbf{1 0 0 , 0}$ \\
\hline
\end{tabular}

\section{Lojistik performans ölçeğine ait keşifsel faktör analizi sonuçları}

Araştırma kapsamında kullanılan lojistik performans ölçeğinin geçerlilik ve güvenirlik çalışması sonuçları aşağıda verilmiştir. Ölçeğe keşifsel faktör analizi yapılabilmesi için verilerin faktör analizine uygunluğunu gösteren KMO değeri ve Barlett Küresellik Testi sonuçları incelenmiştir. Tablo 2' de görüldüğü gibi $\mathrm{KMO}(0,965)$ değeri $0,60^{\prime} \tan$ büyük ve Barlett Küresellik Testi sonucu $(7107,28)$ istatistiksel olarak anlamlı bulunmuştur $(\mathrm{p}<0.01)$. Bu sonuçlar elde edilen örneklem verisinin faktör analizine uygunluğunu göstermektedir (Tabachnick ve Fidell, 2013). Ölçeğin içsel güvenilirliğini belirlemek için Cronbach's Alpha değerleri incelenmiş olup, ölçeğin güvenirlik düzeyinin oldukça yüksek olduğu belirlenmiştir $(\alpha=0,955)$. 
Tablo 2: Lojistik Performans Ölçeğinin Faktör Yük Değerleri

\begin{tabular}{|c|c|c|c|}
\hline & $\begin{array}{l}\text { Faktör } \\
\text { Yükleri }\end{array}$ & $\begin{array}{c}\text { Açıklanan } \\
\text { Varyans }\end{array}$ & $\begin{array}{c}\text { Güvenirlik } \\
\text { Düzeyi }\end{array}$ \\
\hline Maliyet Performansı & & $\% 13,81$ & \multirow{4}{*}{$\mathbf{0 , 9 3 4}$} \\
\hline $\begin{array}{l}\text { Şirketimiz lojistik firmasından nispeten düşük fiyatlar ve yük tarife } \\
\text { ücretleri alabilmektedir. }\end{array}$ & 0,806 & & \\
\hline $\begin{array}{l}\text { Şirketimize lojistik firması tarafından en düşük maliyetli lojistik hizmetler } \\
\text { sağlanır. }\end{array}$ & 0,865 & & \\
\hline Lojistik firması, lojistik maliyetlerin düşürülmesi için çaba sarf eder. & 0,869 & & \\
\hline Operasyonel Performans & & $\% 37,25$ & \multirow{12}{*}{0,965} \\
\hline Lojistik firması, şirketimizin lojistik hizmet ihtiyacını anlar. & 0,881 & & \\
\hline Lojistik firması, teslim tarihlerine uyum açısından güvenilirdir. & 0,835 & & \\
\hline Lojistik firması, teslim sürelerinin azaltılması hususunda çaba sarf eder. & 0,838 & & \\
\hline Siparişler miktar ve ürün olarak doğru/hatasız şekilde teslim edilir. & 0,794 & & \\
\hline $\begin{array}{l}\text { Lojistik firması muayene, yerelleştirme, kapıdan kapıya tek seferlik servis } \\
\text { gibi satış öncesi hizmetler sağlar. }\end{array}$ & 0,793 & & \\
\hline $\begin{array}{l}\text { Lojistik firması, ürünün güvenli bir şekilde teslimi için gerekli şartları } \\
\text { (güvenli teslim için bilgi sağlar) yerine getirir. }\end{array}$ & 0,817 & & \\
\hline Siparişler, herhangi bir zarara uğramadan teslim edilir. & 0,806 & & \\
\hline Lojistik firması ürün güvenlik kurallarına uygun hareket eder. & 0,789 & & \\
\hline $\begin{array}{l}\text { Lojistik firması erken teslim, geç teslim, kaza vb. bir değişiklik } \\
\text { durumunda anlık bilgilendirme yapar. }\end{array}$ & 0,777 & & \\
\hline $\begin{array}{l}\text { Lojistik firması istediğimiz değişiklikleri hızla yerine getirebilme } \\
\text { becerisine sahiptir. }\end{array}$ & 0,809 & & \\
\hline İlişki Performansı & & $\% 23,29$ & \\
\hline Lojistik firması, yaptığımız iş hakkında bilgi sahibidir. & 0,681 & & \multirow{7}{*}{0,907} \\
\hline Lojistik firması, satın alım geçmişimize göre önerilerde bulunur. & 0,748 & & \\
\hline $\begin{array}{l}\text { Lojistik firması karşılıklı hedeflerimizin başarılması için işimize katkı } \\
\text { sağlamaya çalışır. }\end{array}$ & 0,766 & & \\
\hline $\begin{array}{l}\text { Lojistik firması ile birlikte şirketimizin lojistik ihtiyaçlarını tahmin ederek } \\
\text { lojistik firmasının bize ayıracağı kapasiteyi planlarız. }\end{array}$ & 0,756 & & \\
\hline $\begin{array}{l}\text { Lojistik firması ile aramızdaki iletişim sayesinde, işimizle ilgili } \\
\text { düzenlemelerde işbirliği yapabiliriz. }\end{array}$ & 0,782 & & \\
\hline Birbirimizin sürekli gelişimi için önerilerde bulunuruz. & 0,738 & & \\
\hline $\begin{array}{l}\text { Lojistik firması ile aramızda bir problem oluştuğunda kolaylıkla } \\
\text { uzlaşabiliriz. }\end{array}$ & 0,796 & & \\
\hline Toplam Açıklanan Varyans & & $\% 74,32$ & \\
\hline KMO $=0,965$, Bartlett's $\chi 2$ Küresellik Testi $=7107,28, p=0,000$ & & & \\
\hline
\end{tabular}

Tablo 2'ye göre, orijinal ölçektekine benzer şekilde 1. boyut "Maliyet Performansı", 2. boyut "Operasyonel Performans" ve 3. boyut ise; "İlişki Performansı” olarak isimlendirilmiştir. Operasyonel performans boyutu tek başına ölçeğin \%37,25'ini, ilişki performansı boyutu tek başına ölçeğin $\% 23,29^{\prime}$ unu ve maliyet performansı boyutu tek başına ölçeğin \%13,81'ini açılarken üç boyut toplam varyansın \%74,32'ünü açıklamaktadır. Açıklanan varyansın değerinin yeterli olduğu belirlenmiştir.

\section{Lojistik performans ölçeğine ait doğrulayıcı faktör analizi sonuçları}

Lojistik performans ölçeği için Keşifsel Faktör Analiziyle belirlenen üç boyutlu yapı Doğrulayııı Faktör Analizi (DFA) ile de doğrulanmıştır. Bu teste ilişkin DFA diyagramı Şekil 1'de sunulmuştur. 


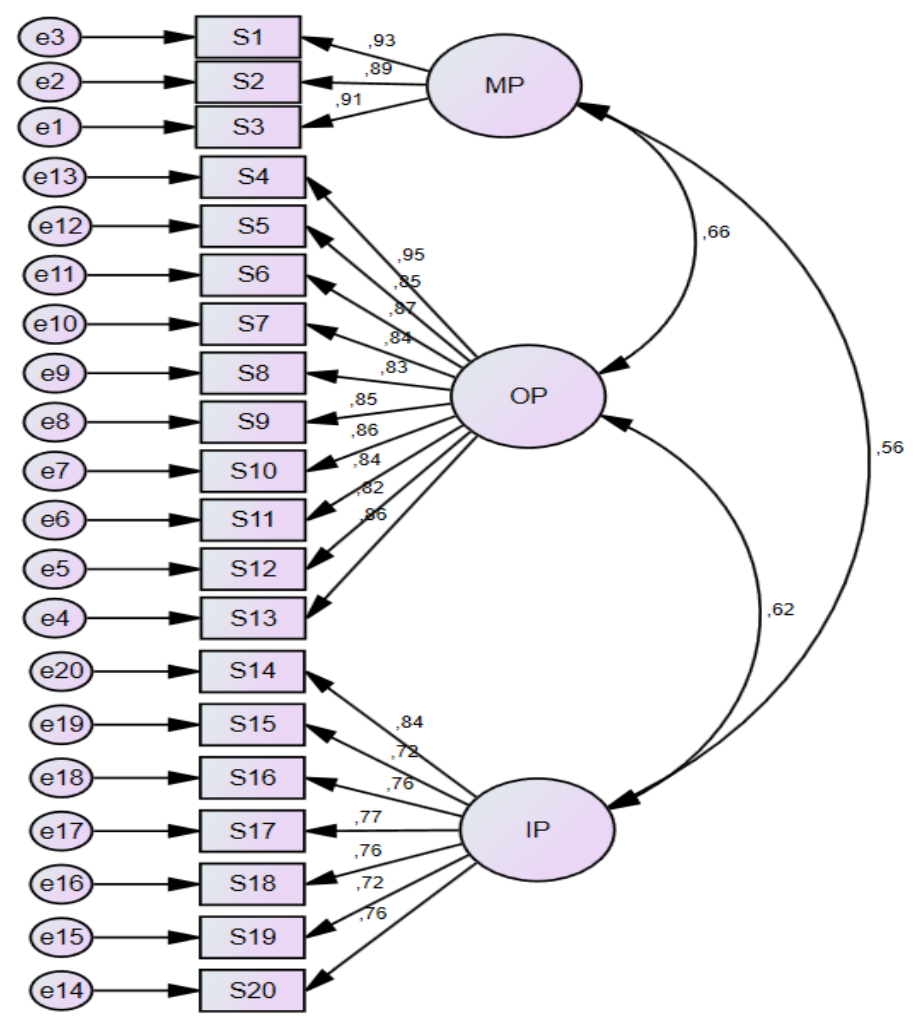

Şekil 1: Lojistik Performansı Ölçeği DFA Diyagramı

DFA ile test edilen modellerin anlamlılı̆̆ın değerlendirmek için kullanılan kriterlerin kabul edilebilir ve mükemmel uyum sinırları Tablo 3'te verilmiştir.

Tablo 3: Uyum İyiliği Kriterleri

\begin{tabular}{ccc}
\hline Uyum Kriterleri & Mükemmel Uyum & Kabul Edilebilir Uyum \\
\hline$\chi 2 / d f$ & $\leq 3$ & $\leq 5$ \\
\hline RMSEA & $0<\mathrm{RMSEA}<0.05$ & $0.05 \leq \mathrm{RMSEA} \leq 0.10$ \\
\hline CFI & $0.95 \leq \mathrm{CFI} \leq 1$ & $0.90 \leq \mathrm{CFI} \leq 0.95$ \\
\hline GFI & $0.95 \leq \mathrm{GFI} \leq 1$ & $0.90 \leq \mathrm{GFI} \leq 0.95$ \\
\hline AGFI & $0.90 \leq \mathrm{AGFI} \leq 1$ & $0.85 \leq \mathrm{AGFI} \leq 0.90$ \\
\hline NFI & $0.95 \leq \mathrm{NFI} \leq 1$ & $0.90 \leq \mathrm{NFI} \leq 0.95$ \\
\hline RMR & $0 \leq \mathrm{RMR}<0.05$ & $0.05 \leq \mathrm{RMR} \leq 0.10$ \\
\hline
\end{tabular}

Kaynak: Schermelleh-Engel, Moosbrugger ve Müler (2003: 52); Demirer ve Bülbül (2014: 104); Xiong, Skitmore ve Xia (2015: 67); Özoğlu ve Bülbül (2017: 776).

Tablo 4'te görüldüğü gibi lojistik performans ölçeği için önerilen modele ait DFA sonucu elde edilen uyum iyiliği değerlerinin çoğunun mükemmel uyum kriterlerine uyduğu belirlenmiştir. En önemli uyum iyiliği değerleri olan $\chi 2 / d f^{\prime}$ in 1,690 ile mükemmel uyum sınırlarında, RMSEA değerinin ise 0,042 ile yine mükemmel uyum sınırlarında olduğu belirlenmiştir. Tablo $4^{\prime}$ te diğer kriterlerden CFI ve NFI mükemmel, GFI'nin de kabul edilebilir uyum aralıklarında olduğu görülmektedir.

Tablo 4: Lojistik Performansı Ölçeği Uyum İyiliği Değerleri

\begin{tabular}{ccccccc}
\hline $\boldsymbol{2} \mathbf{2} \boldsymbol{d} \boldsymbol{f}$ & RMSEA & CFI & GFI & AGFI & NFI & RMR \\
\hline 1,690 & 0,042 & 0,98 & 0,94 & 0,92 & 0,96 & 0,054 \\
\hline
\end{tabular}

\section{Pazarlama performans ölçeğine ait keşifsel faktör analizi sonuçları}

Araştırma kapsamında lojistik işletmelerin pazarlama performansını ölçmek için kullanılan pazarlama performans ölçeğinin geçerlilik ve güvenirlik çalışması sonuçları aşağıda verilmiştir. Ölçeğe keşifsel faktör analizi yapılabilmesi için verilerin faktör analizine uygunluğunu gösteren KMO değeri ve Barlett Küresellik Testi sonuçları incelenmiştir. Tablo 5 'te görüldüğ̈u gibi KMO $(0,965)$ değeri 0,60 'tan büyük ve Barlett Küresellik Testi sonucu $(7695,38)$ istatistiksel olarak anlamlı bulunmuştur $(\mathrm{p}<0.01)$. Bu sonuçlar elde edilen verinin faktör analizine uygunluğunu göstermektedir. Faktör analizi sırasında bazı maddeler çift faktör yükü almış (kararsız bir yapıda olması) ve ortak varyans değeri düşük çıkmış olduğundan analiz dışı bırakılmıştır. Ölçeğin içsel güvenilirliğini belirlemek için Cronbach's Alpha 
değeri incelenmiş̧ olup, ölçeğin güvenirlik düzeyinin oldukça yüksek olduğu belirlenmiştir (Alpha = $0,938)$.

Tablo 5: Pazarlama Performans Ölçeği Faktör Yük Değerleri

\begin{tabular}{|c|c|c|c|}
\hline Maddeler & $\begin{array}{l}\text { Faktör } \\
\text { Yükleri }\end{array}$ & $\begin{array}{c}\text { Açıklanan } \\
\text { Varyans }\end{array}$ & $\begin{array}{l}\text { Güvenirlik } \\
\text { Düzeyi }\end{array}$ \\
\hline Pazarlama İletişimi/Geliştirme & & $\% 19,40$ & \multirow{10}{*}{0,910} \\
\hline Lojistik firmasının fiziksel görünümü sunduğu hizmete uygundur & 0,800 & & \\
\hline Çalıştığımız lojistik firması bizi etkileyen reklam kampanyaları & & & \\
\hline düzenlemektedir & 0,711 & & \\
\hline Çalıştığımız lojistik firması rakiplerine göre hizmet farkl1lıkları yaratır & 0,742 & & \\
\hline Çalıştığımız lojistik firması rakiplerinden daha düşük fiyatlar verir & 0,732 & & \\
\hline $\begin{array}{l}\text { Çalıştığımız lojistik firması çeşitli iletişim kanalları ile hizmetleri hakkında } \\
\text { düzenli olarak bilgilendirme yapmaktadır }\end{array}$ & 0,734 & & \\
\hline $\begin{array}{l}\text { Çalıştığımız lojistik firması müşterilerinin beklenti, istek, öneri ve } \\
\text { görüslerini açkça iletebilecekleri iletisim kanalları sunmaktadır }\end{array}$ & 0,744 & & \\
\hline Çalıştığımız lojistik firması satış sonrası hizmetler vermektedir & 0,787 & & \\
\hline $\begin{array}{l}\text { Çalıştığımız lojistik firması sundukları hizmetlerin çeşitliliğini artırmak için } \\
\text { AR-GE yatırımları yapar }\end{array}$ & 0,769 & & \\
\hline Empati/Güvence & & $\% 18,61$ & \multirow{8}{*}{0,926} \\
\hline Lojistik firması çalışanları kibar/naziktir & 0,781 & & \\
\hline Lojistik firması çalışanları yeterli bilgi düzeyine sahiptir & 0,780 & & \\
\hline Lojistik firması yöneticileri müşterilere bireysel özen/ilgi göstermektedir & 0,743 & & \\
\hline Lojistik firması çalışanları müşterileri ile içtenlikle ilgilenmektedir & 0,780 & & \\
\hline Lojistik firması çalışanları müşteri ihtiyaçları ile ilgili bilgi sahibidir & 0,799 & & \\
\hline Lojistik firması çalışanları müşterilerine bireysel özen/ilgi göstermektedir & 0,780 & & \\
\hline Lojistik firması müşterilerine uygun olan zamanda hizmet sunmaktadır & 0,784 & & \\
\hline Güvenilirlik/ Yanıt Verebilirlik & & $\% 30,26$ & \multirow{12}{*}{0,960} \\
\hline Lojistik firması herhangi bir hizmeti söz verdiği sürede yerine getirmektedir & 0,804 & & \\
\hline Lojistik firması, müşterilerin karşılaştıkları sorunları çözmeye odaklıdır & 0,806 & & \\
\hline Lojistik firması güvenilirdir & 0,845 & & \\
\hline Lojistik firması her türlü hizmeti söz verdiği zamanda sunar & 0,828 & & \\
\hline Lojistik firması kayıtlarını doğru tutar & 0,844 & & \\
\hline Lojistik firması sunacağı hizmetlerin zamanını müşterilerine iletir & 0,838 & & \\
\hline Lojistik firması çalışanları hizmetlerini anında sunmaktadır & 0,817 & & \\
\hline $\begin{array}{l}\text { Lojistik firması çalışanları her zaman müşterilerine yardımcı olmaya } \\
\text { isteklidir }\end{array}$ & 0,837 & & \\
\hline $\begin{array}{l}\text { Lojistik firması çalışanları müşteri isteklerini aksatacak ölçüde yoğun } \\
\text { değildir }\end{array}$ & 0,847 & & \\
\hline Lojistik firması çalışanları müşterilere güven verir & 0,835 & & \\
\hline Lojistik firması hizmet sunduğu müşterilerini güvende hissettirir & 0,856 & & \\
\hline Toplam Açıklanan Varyans & & $\% 68,27$ & \\
\hline
\end{tabular}

KMO $=0,965$, Bartlett's $\chi 2$ Küresellik Testi $=7695,38, p=0,000$

Güvenilirlik/yanıt verebilirlik boyutu tek başına ölçeğin \%30,26'sını, pazarlama iletişimi/geliştirme boyutu tek başına ölçeğin \%19,40'1nı ve empati/güvence boyutu tek başına ölçeğin \%18,61'ini açıklarken, üç boyut toplam varyansın \%68,27'sini açıklamaktadır (Tablo 5). Ölçeğe yönelik toplam açıklanan varyansın \%60'dan büyük olması sosyal bilimler için yeterli görülmektedir (Nakip, 2006).

Tablo 5'e göre, güvenilirlik/yanit verebilirlik boyutunun (cronbach's Alpha $=0,960$ ), pazarlama iletişimi/geliştirme boyutunun (cronbach's alpha $=0,910$ ) ve empati/güvence boyutunun (cronbach's alpha $=0,926$ ) güvenirlik düzeyinin yüksek olduğu belirlenmiştir.

\section{Pazarlama performansı ölçeğine ait doğrulayıcı faktör analizi sonuçları}

Pazarlama performansı ölçeği için Keşifsel Faktör Analiziyle belirlenen üç boyutlu yapı Doğrulayıcı Faktör Analizi (DFA) ile doğrulanmıştır. Bu teste ilişkin DFA diyagramı Şekil 2' de sunulmuştur. 


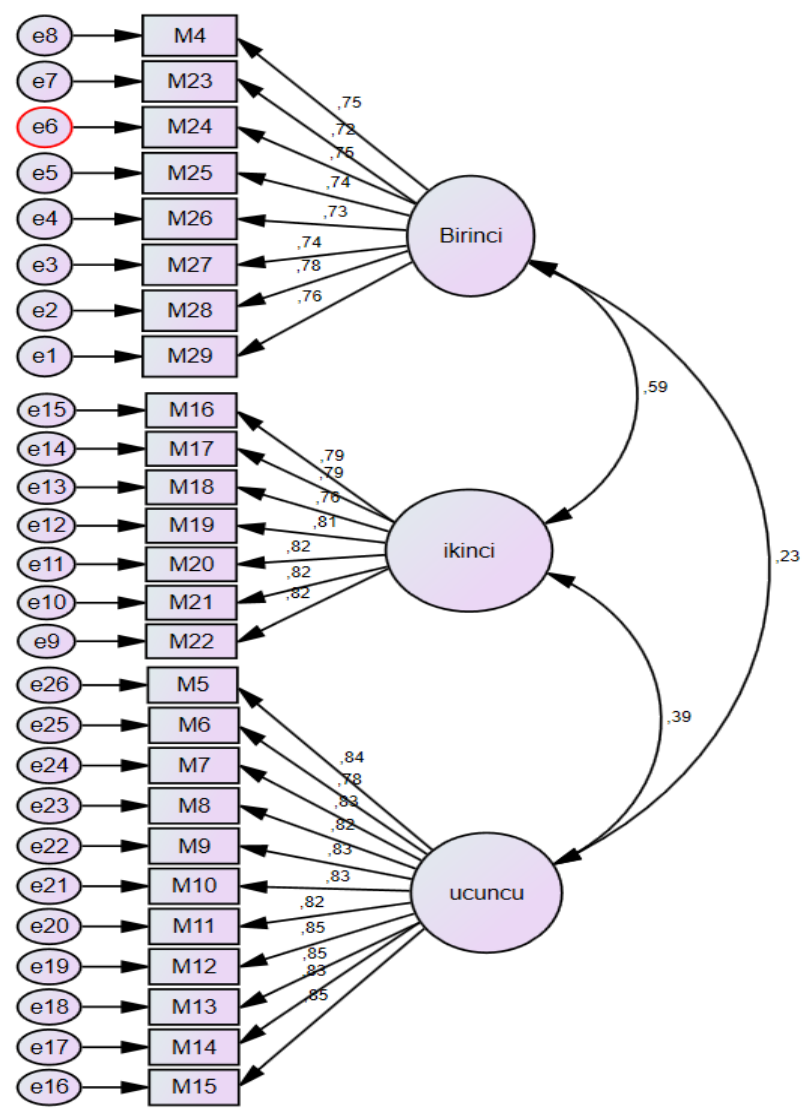

Şekil 2: Pazarlama Performans Ölçeği DFA Diyagramı

Tablo 6'da DFA sonucu elde edilen uyum iyiliği değerlerinin hemen hepsinin mükemmel uyum kriterlerine uyduğu görülmektedir. En önemli uyum iyiliği değeri olan $\chi^{2} / d f^{\prime}$ 'in 1,149 ile mükemmel uyum sınırlarında, RMSEA değerinin ise 0,019 ile yine mükemmel uyum sınırlarında olduğu, CFI'nin mükemmel, GFI'nin de kabul edilebilir uyum aralığında olduğu belirlenmiştir.

Tablo 6: Pazarlama Performans Ölçeği Uyum İyiliği Değerleri

\begin{tabular}{ccccccc}
\hline $\boldsymbol{\chi} \mathbf{2} / \boldsymbol{d} \boldsymbol{f}$ & RMSEA & CFI & GFI & AGFI & NFI & RMR \\
\hline 1,149 & 0,019 & 0,99 & 0,94 & 0,93 & 0,96 & 0,044 \\
\hline
\end{tabular}

\section{Müşteri memnuniyeti ölçeğine ait keşifsel faktör analizi sonuçları}

Araştırma kapsamında üretim işletmelerinin lojistik firmasından memnuniyetini ölçmek için kullanılan müşteri memnuniyeti ölçeğinin geçerlilik ve güvenirliğini incelemek için keşifsel faktör analizi yapılmış ama daha öncesinde faktör analizinin ön şartları sağlayıp sağlamadığı Tablo 7'de belirtilmiştir. Buna göre KMO $(0,854)$ değeri $0,60^{\prime}$ tan büyük ve Barlett Küresellik Testi sonucu $(1177,208)$ istatistiksel olarak anlamlı bulunmuştur $(\mathrm{p}<0.01)$. Dolayısıyla örneklem verisinin faktör analizine uygun olduğu söylenebilir. Ölçeğin içsel güvenilirliğini belirlemek için Cronbach's Alpha değeri incelenmiş olup, ölçeğin güvenirlik düzeyinin oldukça yüksek olduğu belirlenmiştir (Alpha =0,920).

Yapılan faktör analizine göre Tablo 7 incelendiğinde ölçeğin tek boyutlu bir yapıda olduğu ve bu tek boyutun toplam varyansın \% 80,73'ünü açıkladığı belirlenmiştir. Ölçeğin, tek faktörlü yapısından dolayı faktöre ölçeğin kendi adı olan "Müşteri Memnuniyeti" adının verilmesine karar verilmiştir. 
Tablo 7: Müşteri Memnuniyeti Ölçeğinin Faktör Yük Değerleri

\begin{tabular}{|c|c|c|}
\hline & $\begin{array}{l}\text { Faktör } \\
\text { Yükleri }\end{array}$ & $\begin{array}{l}\text { Güvenirlik } \\
\text { Düzeyi }\end{array}$ \\
\hline Maddeler & & 0,920 \\
\hline Çalıştığımız lojistik firmasının şirketimizle olan ilişkisinden memnunuz & 0,928 & \\
\hline Çalıştığımız lojistik firmasının sunduğu hizmetler beklentilerimizi aşmaktadır & 0,892 & \\
\hline Lojistik firmamizla çalışmaktan memnunuz & 0,887 & \\
\hline $\begin{array}{l}\text { Lojistik firmamızla açı, güvene dayalı ve uzun süreli ilişki kurarak, kolaylıkla } \\
\text { çalışabilmekteyiz }\end{array}$ & 0,885 & \\
\hline Açılanan Varyans & $\% 80,73$ & \\
\hline
\end{tabular}

KMO $=0,854$, Bartlett's $\chi 2$ Küresellik Testi $=1177,208, p=0,000$

\section{Müşteri memnuniyeti ölçeğine ait doğrulayıcı faktör analizi sonuçları}

Müşteri memnuniyeti ölçeği için Keşifsel Faktör Analiziyle belirlenen yapı Doğrulayıcı Faktör Analizi (DFA) ile doğrulanmıştır. Bu teste ilişkin DFA diyagramı Şekil 3'te sunulmuştur.

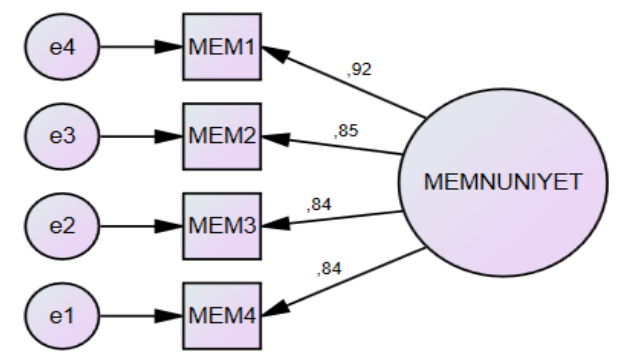

Şekil 3: Memnuniyet Ölçeği DFA Diyagramı

Tablo 8'de görüldüğü gibi DFA sonucu elde edilen uyum iyiliği değerlerinin mükemmel uyum kriterlerine uyduğu belirlenmiştir. En önemli uyum iyiliği değeri olan $x^{2} / d f^{\prime}$ 'in 0,158 ile mükemmel uyum sinırlarında, RMSEA değerinin ise 0,010 ile yine mükemmel uyum sınırlarında olduğu görülmüsştür. CFI, GFI, AGFI, NFI ve RMR'nin de mükemmel uyum kriterleri içerisinde olduğu söylenebilir.

Tablo 8: Müşteri Memnuniyet Ölçeği Uyum İyiliği Değerleri

\begin{tabular}{ccccccc}
\hline $\boldsymbol{\chi} \mathbf{2} / \boldsymbol{d} \boldsymbol{f}$ & RMSEA & CFI & GFI & AGFI & NFI & RMR \\
\hline 0,158 & 0,010 & 0,99 & 0,99 & 0,99 & 0,99 & 0,003 \\
\hline
\end{tabular}

\section{Yapısal modellerin analizi}

AMOS programı yardımı ile Doğrulayıcı Faktör Analizine tabii tutularak doğrulanan yapılar arasındaki ilişkiler ise yapısal eşitlik modelleri kullanılarak yine AMOS programı yardımı ile analiz edilmiştir.

\section{Lojistik performansın pazarlama performansına etkisi}

Araştırmanın birinci modeli olan lojistik performansın lojistik firmalarının pazarlama performansı üzerindeki etkisine ait modelinin test edilmesinde uyum iyiliği değerleri ve beta katsayıları incelenmiştir. Araştırma modeline ait YEM analizi yol diyagramı Şekil 4'te, analiz sonuçları ise özet olarak Tablo 9'da verilmiştir.

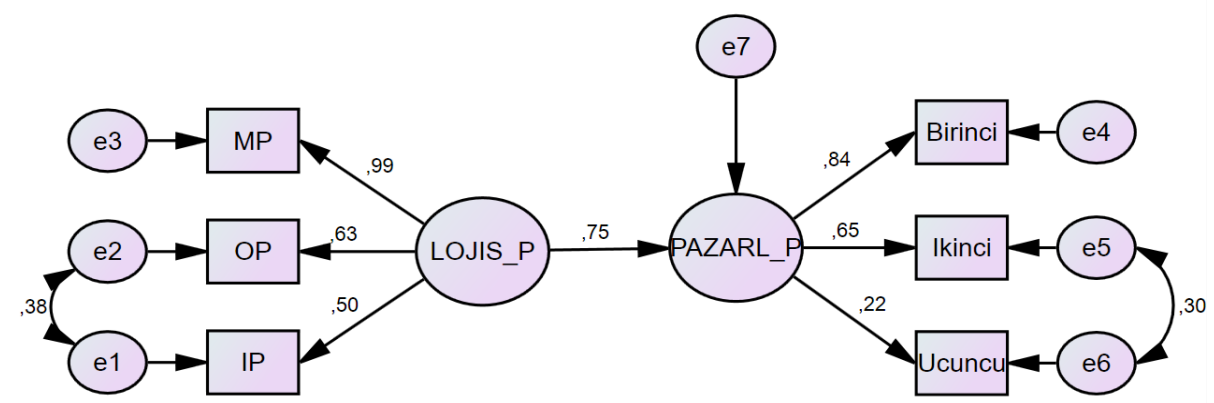

Şekil 4: Birinci Araştırma Modeline Ait Yol Diyagramı 
Birinci araştırma modeline ait sonuçlar Tablo $9^{\prime}$ da yer almaktadır. Buna göre lojistik performansın pazarlama performansı üzerindeki etkisi incelendiğinde, lojistik performansın pazarlama performansı üzerinde $0,75^{\prime}$ lik olumlu bir etkisi olduğu istatistiksel olarak \%99 güven düzeyinde belirlenmiştir $(\beta=0,75 ; \mathrm{t}=9,24>2,58 ; \mathrm{p}<0.01)$. Bu sonuç, lojistik performansta bir artış olduğunda pazarlama performansı düzeylerinde de $0,75^{\prime}$ lik bir artışa neden olacağını ifade etmektedir. Lojistik performansın tek başına pazarlama performansının \%57'sini açıkladığı $\left(\mathrm{R}^{2}=0,57\right)$ belirlenmiştir.

Tablo 9: Birinci Araştırma Modeline Ait Sonuçlar

\begin{tabular}{lccc}
\hline \multicolumn{1}{c}{ Yollar } & $\beta$ & $\boldsymbol{t}$ değerleri & $\mathbf{R}^{\mathbf{2}}$ \\
\hline$($ LOJIS_P) $\rightarrow$ (PAZARL_P) & 0,75 & $9,24^{* *}$ & 0,57 \\
\hline${ }^{* *} \mathrm{p}<0.01$ & &
\end{tabular}

Önerilen modelin kabul edilebilir olması için tabloda belirtilen tüm uyum iyiliği kriterlerinin kabul edilebilir sınırlar içinde olması gerekmektedir. Araştırma modelinin uygunluğuna yönelik uyum iyiliği kriterleri incelendiğinde (Tablo 10), $x 2 / d f$, RMSEA, CFI, GFI, AGFI, NFI ve RMR kriterlerinin mükemmel uyum sınırları içinde yer aldığı görülmektedir.

Tablo 10: Birinci Araştırma Modeline Ait Uyum İyiliği Değerleri

\begin{tabular}{ccccccc}
\hline $\boldsymbol{2} \mathbf{2} / \boldsymbol{d} \boldsymbol{f}$ & RMSEA & CFI & GFI & AGFI & NFI & RMR \\
\hline 1,464 & 0,034 & 0,99 & 0,99 & 0,98 & 0,99 & 0,018 \\
\hline
\end{tabular}

En önemli uyum indeksi değeri olan $\chi 2 / d f$ değerinin 1,464 ve RMSEA değerinin 0,034 ile mükemmel uyum aralığında, bunun yanı sıra diğer uyum kriterlerinin de mükemmel uyum aralığında oldukları belirlenmiştir. Buna göre, lojistik performansın pazarlama performansı üzerindeki etkisinin araştırılmasına yönelik kurulan modelin geçerli bir model olduğu ifade edilebilir.

\section{Lojistik performansın müşteri memnuniyetine etkisi}

Araştırmanın ikinci modeli olan lojistik performansın üretim işletmelerinin müşteri memnuniyeti üzerindeki etkisine ait modelin test edilmesinde uyum iyiliği değerleri ve beta katsayıları incelenmiştir. Araştırma modeline ait YEM analizi yol diyagramı Şekil 5'te, analiz sonuçları ise özet olarak Tablo 11'de verilmiştir.

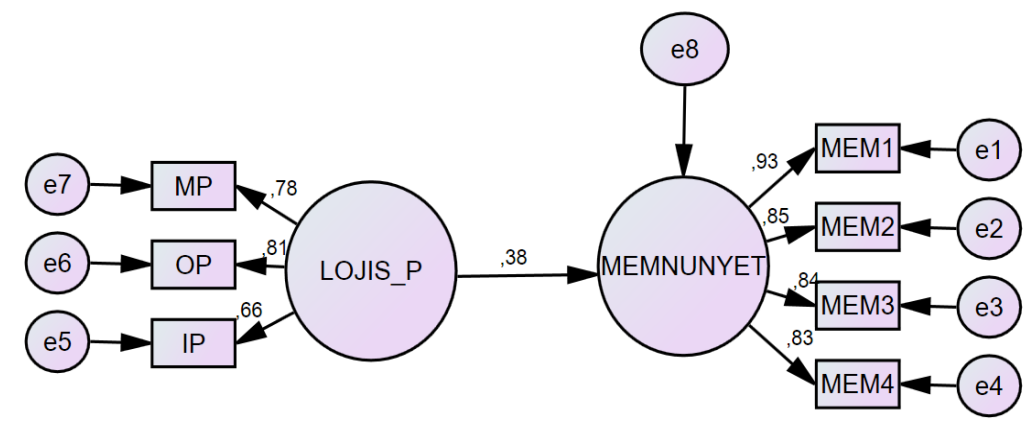

Şekil 5: İkinci Araştırma Modeline Ait Yol Diyagramı

İkinci araştırma modeline ait sonuçlar Tablo 11'de verilmiştir. Buna göre, lojistik performansın müşteri memnuniyeti üzerindeki etkisi incelendiğinde, lojistik performansın müşteri memnuniyeti üzerinde $0,38^{\prime}$ lik olumlu bir etkisi olduğu istatistiksel olarak \%99 güven düzeyinde belirlenmiştir $(\beta=0,38$; $\mathrm{t}=6,35>2,58 ; \mathrm{p}<0.01)$. Bu sonuç, lojistik performansta bir artış olduğunda müşteri memnuniyeti düzeylerinde de 0,38'lik bir artışa neden olacağını ifade etmektedir. Lojistik performansın tek başına müşteri memnuniyetinin $\% 14^{\prime}$ ünü açıkladığı $\left(R^{2}=0,14\right)$ belirlenmiştir.

Tablo 11: İkinci Araştırma Modeline Ait Sonuçları

\begin{tabular}{lccc}
\hline \multicolumn{1}{c}{ Yollar } & $\beta$ & $\boldsymbol{t}$ değerleri & $\mathbf{R}^{\mathbf{2}}$ \\
\hline$($ LOJ_F $\rightarrow$ (MEMNUNYT) & 0,38 & $6,35^{* *}$ & 0,14 \\
\hline${ }^{* *} \mathrm{p}<0.01$ & & &
\end{tabular}

Araştırma modelinin uygunluğuna yönelik uyum iyiliği kriterleri incelendiğinde (Tablo 12), $\chi 2 / d f$, RMSEA, RMR, NFI, CFI, GFI ve AGFI kriterlerinin mükemmel uyum sınırları içinde yer aldığı görülmektedir. 
Tablo 12: İkinci Araştırma Modeline Ait Uyum İyiliği Değerleri

\begin{tabular}{ccccccc}
\hline $\boldsymbol{\chi 2} / \boldsymbol{d} \boldsymbol{f}$ & RMSEA & CFI & GFI & AGFI & NFI & RMR \\
\hline 2,623 & 0,064 & 0,99 & 0,98 & 0,95 & 0,98 & 0,06 \\
\hline
\end{tabular}

En önemli uyum iyiliği değeri olan $\chi^{2} / d f^{\prime}$ 'in 2,623 ile mükemmel uyum aralığında, RMSEA değerinin 0,064 ile kabul edilebilir uyum aralığında, diğer uyum kriterlerinin de mükemmel uyum aralığında oldukları belirlenmiştir. Lojistik performansın müşteri memnuniyeti üzerindeki etkisinin araştırılmasına yönelik kurulan modelin geçerli bir model olduğu ifade edilebilir.

\section{Lojistik performansın pazarlama performansı ve müşteri memnuniyetine etkisi}

Araştırmanın üçüncü modeli olan lojistik performansın lojistik firmaların pazarlama performansı ve üretim işletmelerinin müşteri memnuniyeti üzerindeki etkisi ve lojistik firmaların pazarlama performansının üretim işletmelerinin müşteri memnuniyetine etkisini bir arada inceleyen modelinin test edilmesinde uyum iyiliği değerleri ve beta katsayıları incelenmiştir. Araştırma modeline ait YEM analizi yol diyagramı Şekil $6^{\prime}$ da, modelin istatistiksel bakımdan anlamlı ve geçerli olduğunu gösteren uyum iyiliği sonuçları ise özet olarak Tablo $13^{\prime}$ de verilmiştir.

Tablo 13: Üçüncü Araştırma Modeline Ait Uyum İyiliği Değerleri

\begin{tabular}{ccccccc}
\hline $\mathbf{X}^{2} / \mathbf{d f}$ & RMSEA & CFI & GFI & AGFI & NFI & RMR \\
\hline 3,742 & 0,083 & 0,963 & 0,949 & 0,906 & 0,951 & 0,062 \\
\hline
\end{tabular}

Araştırma modelinin uygunluğuna yönelik uyum iyiliği kriterleri Tablo 13 'de görülmektedir. En önemli uyum iyiliği değeri olan $\chi^{2} / d f^{\prime}$ in 3,742 ile kabul edilebilir, RMSEA değerinin 0,083 ile yine kabul edilebilir uyum aralığında oldukları belirlenmiştir. Diğer uyum kriterleri incelendiğinde ise; Tablo 13'de görüldüğü gibi RMR ve NFI kabul edilebilir; CFI, GFI, AGFI mükemmel uyum kriterlerinin sınırları içinde yer almaktadır.

Tablo 13'deki sonuçlara göre Şekil 6' da yer alan modeldeki değişkenler ve hesaplanan değerler istatistiksel olarak kullanılabilir niteliktedir. Lojistik performansın pazarlama performansı, lojistik performansın müşteri memnuniyeti ve pazarlama performansının müşteri memnuniyeti üzerine etkisinin araştırılmasına yönelik kurulan modelin geçerli bir model olduğu ifade edilebilir. Bu doğrultuda değişkenlerle ilgili modeldeki ilişkiler yorumlanmıştır.

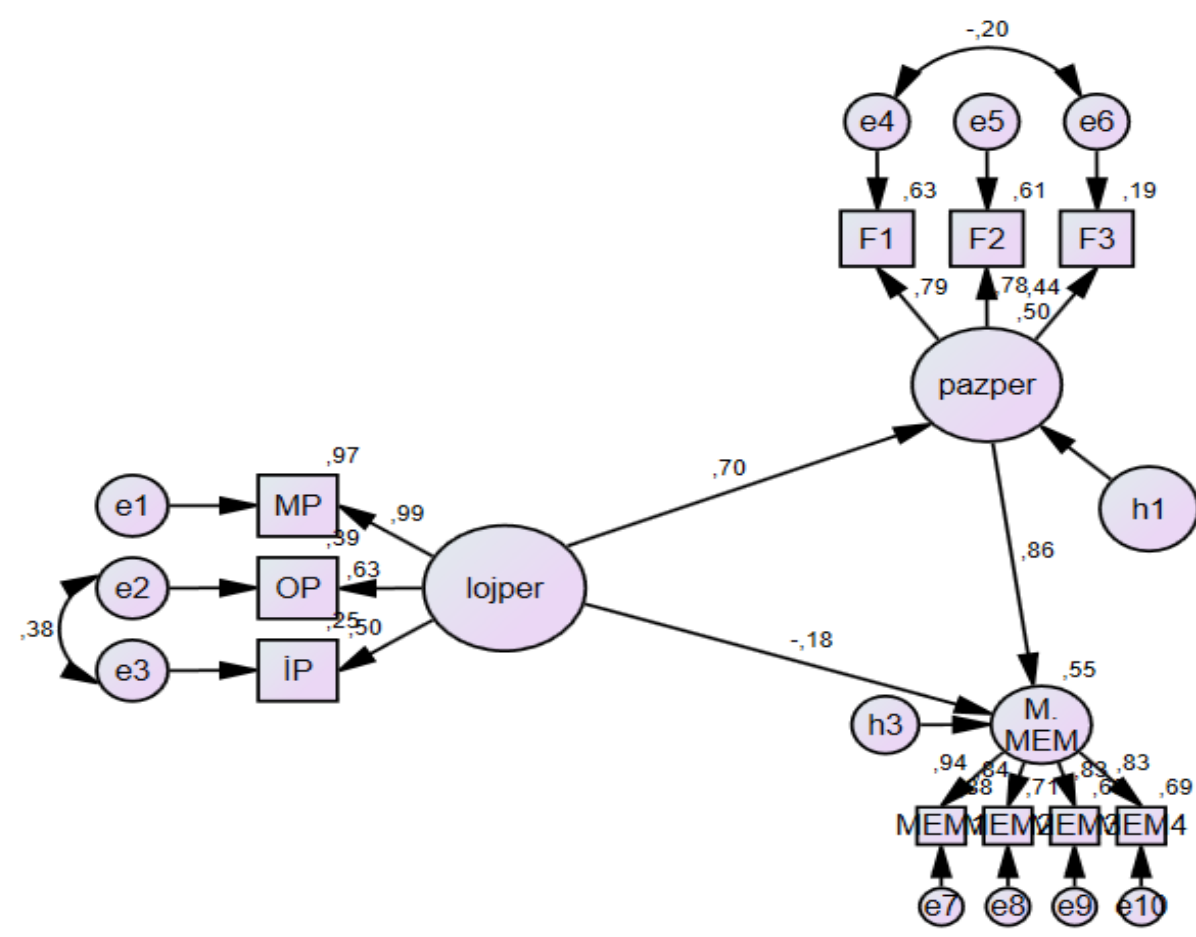

Şekil 6: Araştırmanın Üçüncü Modeline Ait Yol Diyagramı 
Modelde lojistik performansın pazarlama performansı üzerine $0,70^{\prime}$ lik olumlu bir etkisi olduğu; pazarlama performansının müşteri memnuniyeti üzerine $0,86^{\prime}$ lık olumlu bir etkisi olduğu istatistiksel olarak \%99 güven düzeyinde belirlenmiştir. Bu sonuç, lojistik performansta bir birim artış olduğunda pazarlama performansında $\% 0,70$ artış olacağını $(\beta=0,70 ; \mathrm{t}=8,47>2,58 ; \mathrm{p}<0.01)$ ve pazarlama performansındaki bu artışın da müşteri memnuniyeti düzeylerinde $0,86^{\prime}$ lık bir artışa neden olacağını $(\beta=0,86 ; t=8,81>2,58 ; p<0.01)$ ifade etmektedir. Lojistik performansin pazarlama performansınin $\% 50^{\prime}$ lik çok önemli bir kısmını açıladığı belirlenmiştir. Lojistik performansın müşteri memnuniyetine 0,01 düzeyinde anlamlı olan \%38'lik etkisi pazarlama performansının modele eklenmesi ile 0,01 düzeyinde değil 0,05 düzeyinde anlamlı hale geldiğinden, pazarlama performansının kısmi aracılık etkisinden bahsedebiliriz. Bir değişkenin aracılık etkisi söz konusu ise, o değişken modele dahil edildikten sonra doğrudan ilişkileri yok etmesi durumunda tam aracılık, ilişkinin gücünü azaltması durumunda kısmi aracilıktan behsedilebilir (Gürbüz ve Demirer, 2018: 1694).

Bu etkinin geçerliliğinin belirlenebilmesi için Sobel Testi yapılmıştır (Sobel testi web sitesi). Test sonuçları (Sobel test istatistiği $=6.107$; Std. Sapma $=0.240 ; p=0.00$ ) aracılık etkisinin anlamlılığını göstermektedir. Dolayısıyla kısmi aracılık etkisi yorumlanabilirdir ve buna göre işletmelerin lojistik performansının müşteri memnuniyetine etkisine pazarlama performansı aracılık etmektedir. Böylece, lojistik performans tek başına müşteri memnuniyetinin \%14'ünü açıklarken, pazarlama performansının kısmi aracılık etkisi ile müşteri memnuniyetinin $\% 55$ 'i gibi yüksek bir oranda açılandığ anlaşılmaktadır.

\section{Sonuç ve değerlendirme}

Küresel rekabet işletmelerin birbirlerinden farklı kabiliyetlere ve temel yeteneklerine odaklanmalarını zorunlu kılmıştır. Bu doğrultuda önemi artan lojistik faaliyetleri temel yeteneği olarak belirleyen lojistik hizmet sağlayıcıların önemi ve üretim işletmelerinin başarısına etkisi giderek artmıştır.

İşletmelerin lojistik performansının pazarlama performansına ve müşteri memnuniyetine etkisini araştıran bu çalışma, üretim işletmelerinin gözünden lojistik işletmelerinin lojistik performansını ve pazarlama performansını değerlendirmesi açısından önemlidir. Çalışmanın ana amacına ulaşmak için gerçekleştirilen analizler sonucunda işletmelerin lojistik performansını ölçmek için kullanılan ölçeğin üç temel boyuttan oluştuğu bulgusuna ulaşılmıştır. Bu boyutlar literatürdeki çalışmalarla benzer şekilde maliyet performansı, operasyonel performans ve ilişki performansı olarak belirlenmiştir. Bu üç boyutun lojistik performansın yaklaşık \%74'ünü açılkladığı ve bu boyutlardan operasyonel performansın lojistik performansı açıklama gücünün diğer boyutlara göre oldukça yüksek olduğu söylenebilir. Açıklama gücü açısından daha sonra ilişki performansı ve son olarak da maliyet performansı gelmektedir. Buradan hareketle işletmelerin lojistik performansının iyileştirilmesinde öncelikle lojistik ihtiyaçların anlaşılması, teslim tarihleri, süreleri gibi operasyonel konuların üzerinde durulması önerilebilir. İlişki performansının iyileştirilmesi açısından da uzlaşıya ve işbirliğine yönelik iletişim geliştirme, çözüm odaklı olma ve işletme hedeflerine birlikte odaklanma konularının üzerinde durulması önerilebilir.

Diğer taraftan, bu çalışmada yine üç boyutlu olarak belirlenen Pazarlama Performansı Ölçeği lojistik işletmelerin pazarlama performansını $\% 68,27$ oranında açıklamaktadır. Bu oranın nispeten düşük olması pazarlama performans kriterlerinin son derece çeşitli olması ve daha önce çokça araştırılmış olan finansal kriterlerin bu çalışmada tercih edilmemiş olması ile açıklanabilir. Pazarlama performansını açıklayan üç boyuttan \%30 gibi yüksek bir açıklama oranı olan güvenilirlik/yanıt verebilirlik boyutu olarak belirlenmiş̧ir. Buna göre, lojistik hizmet sağlayıcıların üretim işletmelerine verdikleri hizmetlerle ilgili söz verdiği sürede yerine getirme, güvenilir olma, sorunlara hızlı çözüm getirme noktalarına odaklanmaları önerilebilir.

Araştırma bulgularına göre; lojistik performansın pazarlama performansı üzerinde 0,75'lik olumlu bir etkisi olduğu belirlenmiştir. Bu bulguya göre lojistik performansta bir birim artış olduğunda pazarlama performansı düzeylerinde de 0,75'lik bir artışa neden olacaktır. Ayrıca, lojistik performansın müşteri memnuniyeti üzerinde $0,38^{\prime}$ lik olumlu bir etkisi olduğu bulunmuştur. Lojistik performansta bir artı̧ olduğunda müşteri memnuniyeti düzeylerinde de 0,38'lik bir artışa neden olacaktır. Buradan hareketle lojistik performans artışının pazarlama performansı üzerinde oldukça yüksek bir etkisi olduğu, müşteri memnuniyeti üzerinde ise hiç de azımsanmayacak bir etkisinin olduğu söylenebilir.

Son araştırma modeline göre lojistik performansın müşteri memnuniyetine etkisine pazarlama performansı aracılık etmektedir. Lojistik performansın müşteri memnuniyetine 0,01 düzeyinde anlamlı olan \%38'lik etkisi pazarlama performansının modele eklenmesi ile 0,01 düzeyinde değil 0,05 düzeyinde anlamlı hale geldiğinden pazarlama performansının kısmi aracılık etkisinden bahsederiz. Böylece, lojistik performans tek başına müşteri memnuniyetinin \%14'ünü açıklarken, pazarlama performansının 
kısmi aracılık etkisi ile müşteri memnuniyetinin \%55'i gibi yüksek bir oranda açılandığ1 görülmektedir. Bu noktada, bu çalışmanın aksine doğrudan ilişkiye odaklanılarak yapılan literatür taramasında az sayıda çalışmanın lojistik performansın müşteri memnuniyetine doğrudan etkisini tespit etmiş olması (Leuschner vd., 2012; Ltifi ve Gharbi, 2015) nedeniyle konunun ampirik olarak araştırılmaya muhtaç olduğu belirtilebilir. Diğer taraftan, lojistik performansın müşteri memnuniyetine pazarlama performansının kısmi aracılık etkisinin beklenen bir durum olduğu söylenebilir. İşletmelerin lojistik performanslarını arttırmalarının son derece kritik olduğu ancak pazarlama performansının müşteri memnuniyeti üzerindeki rolünün de azımsanmaması gerektiği söylenebilir. Bu doğrultuda lojistik hizmet sağlayıcılara sundukları hizmetin yanı sıra pazarlama performansı için de çaba göstermeleri önerilebilir.

Pazarlama performans kriterlerinin son derece çeşitli olması ve bu çalışmada finansal kriterlerin tercih edilmemiş olması nedeniyle ilerleyen çalışmalarda farklı pazarlama performansı kriterleri çalışma kapsamına alınarak lojistik işletmelerin pazarlama performansı yeniden değerlendirilebilir. Ayrıca, lojistik performansın müşteri memnuniyetine literatürde sınırlı çalışmayla incelenen doğrudan etkisi farklı örneklemlerde incelerek literatüre katkı sağlanabilir.

\section{Hakem Değerlendirmesi / Peer-review:}

Dış bağımsız

Externally peer-reviewed

\section{Çıkar Çatışması / Conflict of interests:}

Yazar(lar) çıkar çatışması bildirmemiştir.

The author(s) has (have) no conflict of interest to declare.

\section{Finansal Destek / Grant Support:}

Bu çalışma Dr. Öğr. Üyesi Buket ÖZOĞLU danışmanlığında M. Burak ERDEMİR tarafından hazırlanan ve SBT 2020/1-LÜTEP kapsamında Niğde Ömer Halisdemir Üniversitesi Bilimsel Araştırma Projeleri Koordinasyon Birimi tarafından desteklenen tez çalışmasından üretilmiştir.

This study was produced from the Master's thesis prepared by M. Burak ERDEMIR under the supervision of Buket ÖZOĞLU and supported by the Scientific Research Projects Coordination Unit of Niğde Ömer Halisdemir University within the scope of SBT 2020/1-LÜTEP.

\section{Teşekkür / Acknowledgement:}

Bu çalışmanın gerçekleşmesindeki katkıları dolayısıyla Niğde Ömer Halisdemir Üniversitesi Bilimsel Araştırma Projeleri Koordinasyon Birimine teşekkür ederiz.

Thanks to Niğde Ömer Halisdemir University Scientific Research Projects Coordination Unit for their support of this study.

\section{Etik Kurul Onayı / Ethics Committee Approval:}

Bu çalışma için etik kurul onayı, Niğde Ömer Halisdemir Üniversitesi Etik Kurulu/Komitesinden 07/12/2020 tarihli 10 sayılı karar ile alınmıştır.

Ethics committee approval was received for this study from Niğde Ömer Halisdemir University, Niğde Ömer Halisdemir University Ethics Committee on 07/12/2020 and 10 document number.

\section{Yazar Katkıları / Author Contributions}

Fikir/Kavram/Tasarım - Idea/Concept/Design: B.Ö. Veri Toplama ve/veya İsleme - Data Collection and/or Processing: M.B.E. Analiz ve/veya Yorum - Analysis and/or Interpretation: B.Ö., M.B.E. Kaynak Taraması - Literature Review: M.B.E. Makalenin Yazımı - Writing the Article: B.Ö., M.B.E. Eleştirel İnceleme Critical Review: B.Ö. Onay - Approval: B.Ö., M.B.E. 


\section{Kaynakça / References}

Akdoğan, M. Ş., \& Durak, A. (2016). Logistic and Marketing Performances of Logistics Companies: A Comparison between Germany and Turkey. In: Proceedings of the 12th International Strategic Management Conference. Antalya: Turkey.

Altunışık, R., Coşkun, R., Bayraktaroğlu, S., \& Yıldırım, E. (2007). Sosyal Bilimlerde Araştırma Yöntemleri: SPSS Uygulamalı. (Geliştirilmiş 5.Baskı). Adapazarı: Sakarya Yayıncılık.

Ambler, T. Kokkinaki, F., \& Puntoni, S. (2004). Assessing Marketing Performance: Reasons for Metrics Selection. Journal of Marketing Management, 20(3-4), 475-498, DOI: 10.1362/026725704323080506.

Bozacı, İ. (2014). Müşteri Güçlendirme ile Pazarlama Performansı İlişkisi: Mobilya Sektörüne Yönelik Bir Uygulama (Doktora tezi). Kırıkkale Üniversitesi Sosyal Bilimler Enstitüsü, Kırıkkale.

Daugherty, P. J., Chen, H., Mattioda, D. D., \& Grawe, S. J. (2009). Marketing/Logistics Relationships: Influence on Capabilities and Performance. Journal of Business Logistics, 30(1), 1-18.

Demirer, Ö., \& Bülbül, H. (2014). Kamu ve Özel Hastanelerde Hizmet Kalitesi, Hasta Tatmini ve Tercihi Arasındaki İlişki: Karşılaştırmalı Bir Analiz. Amme İdaresi Dergisi, 47(2), 95-119.

Doney, P., \& Cannon, J. (1997). An Examination of the Nature of Trust in Buyer-Seller Relationships. Journal of Marketing, 61(2), 35-51. doi:10.2307/1251829

Ellinger, A. E., Daugherty, P. J., \& Keller, S. B. (2000). The Relationship Between Marketing/Logistics Interdepartmental Integration and Performance in US Manufacturing Firms: An Empirical Study. Journal of Business Logistics, 21(1), 1-22.

Fabbe-Costes, N., \& Jahre, M. (2007). Supply Chain Integration Improves Performance: The Emperor's New Suit? International Journal of Physical Distribution \& Logistics Management, 37(10), 835-855.

Fawcett, S. E., Stanley, L. L., \& Smith, S. R. (1997). Developing a Logistics Capability to Improve The Performance of International Operations. Journal of Business Logistics, 18(2), 101-127.

Fugate, B. S., Mentzer, J. T., \& Stank, T. P. (2010). Logistics Performance: Efficiency, Effectiveness and Differentiation. Journal of Business Logistics, 31 (1), 43-62.

Gimenez, C., \& Ventura, E. (2005). Logistics-Production, Logistics-Marketing and External integration: Their Impact on Performance. International Journal of Operations \& Production Management, 25(1), 231-249.

Green, Jr K. W., Whitten, D., \& Inman, R. A. (2008). The Impact of Logistics Performance on Organizational Performance in a Supply Chain Context. Supply Chain Management: An International Journal, 13(4), 317-327.

Grønholdt, L., \& Martensen, A. (2006). Key Marketing Performance Measures. The Marketing Review, $6(3), 243-252$.

Gürbüz, E., \& Demirer, Ö. (2018). Rekabetçi Öncelikler ve Firma Performansı Üzerinde İleri İmalat Teknolojilerinin Aracılık Etkisi. Hitit Üniversitesi Sosyal Bilimler Enstitüsü Dergisi, 11(3), 1681-1699. DOI: $10.17218 /$ hititsosbil.482932

Hacıoğlu, G., \& Gök, O. (2013). Marketing Performance Measurement: Marketing Metrics in Turkish Firms. Journal of Business Economics and Management, 14(1), 413-432.

Ilic, D. \& Tesic, A. (2016). The Relationship Between Supply Chain Management Strategy, Marketing, Logistics and Company Performance for Breweries in Serbia. Economics of Agriculture, 63(4), 11571168.

Leuschner, R., Lambert, D. M., \& Knemeyer, A. M. (2012). Logistics Performance, Customer Satisfaction, and Share of Business: A Comparison of Primary and Secondary Suppliers. Journal of Business Logistics, 33(3), 210-226.

Li, L. (2011). Assessing The Relational Benefits of Logistics Services Perceived by Manufacturers in Supply Chain. International Journal of Production Economics, 132(1), 58-67.

Ltifi, M., \& Gharbi, J. (2015). The Effect of Logistics Performance in Retail Store on The Happiness and Satisfaction of Consumers. Proced. Econ. Financ. (Elsevier) 23, 1347-1353.

Marr, B., \& Schiuma, G. (2003). Business Performance Measurement - Past, Present and Future. Management Decision, 41(8), 680-687. 
Morash, E. A., Dröge, C., \& Shawnee, K. V. (1996). Boundary Spanning Interfaces between Logistics, Production, Marketing and New Product Development. International Journal of Physical Distribution and Logistics Management, Special Issue on Interfunctional Coordination of Logistics with Other Business Functions, 26(8), 43-62.

Nakip, M. (2006). Pazarlama Araştırmaları: Teknikler ve (SPSS Destekli) Uygulamalar. 2. Baskı, Ankara: Seçkin Yayıncllı.

Özoğlu, B., \& Bülbül, H. (2017). İçgüdüsel Satın Alma ve Demografik Özellikler ile İlişkisi: Teknoloji ve Giyim Ürünlerinde Karşılaştırmalı Bir Analiz. Süleyman Demirel Üniversitesi İktisadi ve İdari $\begin{array}{llll}\text { Bilimler } \quad \text { Fakültesi } & \text { Dergisi, 22(3), }\end{array}$ https://dergipark.org.tr/en/pub/sduiibfd/issue/52994/704155

Özoğlu, B., \& Büyükkeklik, A. (2017). An Analysis of Third Party Logistics' Performance and Customer Loyalty. International Journal of Marketing Studies, 9(6), 55-67.

Qadir, I., \& Amjad, A. (2017). Importance of Logistics Processes for Customer Service and Firm Performance: Evidence from Furniture Industry of Pakistan. Management. Journal of Sustainable Business and Management Solutions in Emerging Economies, 22(3), 27-36.

Schermelleh-Engel, K., Moosbrugger, H., \& Müler, H. (2003). Evaluating the Fit of Structural Equation Models: Tests of Significance and Descriptive Goodness-of-Fit Measures. Methods of Psychological Research Online, 8(2), 23-74.

Sezen, B. (2005). The Role of Logistics in Linking Operations and Marketing and Influences on Business Performance. Journal of Enterprise Information Management, 18(3), 350-356. https://doi.org/10.1108/17410390510592012.

Sobel testi web sitesi http://quantpsy.org/sobel/sobel.htm

Stank, T. P., Daugherty, P. J., \& Ellinger, A. E. (1999). Marketing/Logistics Integration and Firm Performance. The International Journal of Logistics Management, 10(1), 11-24.

Tabachnick, B. G., \& Fidell, L. S. (2013). Using Multivariate Statistics, (6th ed). Boston: Pearson.

Vallet-Bellmunt, T., \& Rivera-Torres, P. (2018). The Relationship Between Logistics and Marketing Performance in the Supply Chain. Different Paths for Manufacturers and Distributors. Universia Business Review, 60, 90-135. DOI: 10.3232/UBR.2018.V15.N4.03.

Xiong, B., Skitmore, M., \& Xia, B. (2015). A Critical Review of Structural Equation Modeling Applications in Construction Research. Automation in Construction, 49, 59-70. 